\title{
The Use of Animal Bone as Fuel in the Third Millennium BC Walled Enclosure of Castanheiro do Vento (Northern Portugal)
}

\section{C. $\cos T A^{*}$}

ICArEHB, International Center for Archaeology and Evolution of Human Behavior, University of Algarve, Faro, Portugal

\begin{abstract}
Experiments on fire manipulation of bones as fuel demonstrated that animal bones are effective in the act of maintaining lasting combustion. These experiments are almost always applied to the studies in hunter-gather societies in prehistory, even though the use of bones as fuel is also known in historical times.

Based on data and models resulting from these recent experiments, both in laboratory and in real hearths, I tested the hypothesis of the use of animal bone as fuel in the third/second millennium BC walled enclosure of Castanheiro do Vento, in northern Portugal. The faunal assemblage shows some specific characteristics such as a very low percentage of identifiable material and close to $90 \%$ of charred bones with a very high index of fragmentation

I link the faunal analysis with the results of some experiments recently published. These experiments show the particularities of bone fuel combustion, specifically used in certain activities. Nevertheless, the interpretation of these activities in Castanheiro do Vento is difficult to achieve because of the preliminary state of the investigations. As an additional problem, the available interpretations in the literature concern mostly hunter-gather, and models do not take into account the complex societies of the third/second millennium BC. Copyright (C) 2015 John Wiley \& Sons, Ltd.
\end{abstract}

Key words: animal bones; bone as fuel; calcination; northern Portugal; third millennium BC; walled enclosure

\section{Introduction}

One of the most common marks of anthropogenic manipulation in archaeofaunal collections dating from prehistoric periods is related to the use of fire that is an important taphonomic signature. These marks are often interpreted as a result of processing of meat for food, the final stage of trash removal and site maintenance or rituals using fire. The observation of elements on bone resulting from thermal alteration, together with experimental studies that recently have been conducted, shows that the thermal handling of the faunal remains should not be so simplistically related with cooking meat or cleaning habitats. Rather, experimental work revealed a multitude of activities including the use of bones as raw material directly used in the act of 'making fire'.

The development of these experimental studies have focused mainly on the meaning of thermally manipulated faunal assemblages dated from Pleistocene archaeological contexts (Théry-Parisot, 2002; Villa et al., 2002;

\footnotetext{
* Correspondence to: Cláudia Costa, ICArEHB - International Center for Archaeology and Evolution of Human Behavior, University of Algarve. e-mail: cmcosta@ualg.pt
}

Costamagno et al., 2005; Théry-Parisot et al., 2005; Yravedra et al., 2005; Glazewski, 2006; Costamagno et al., 2009; Dibble et al., 2009; Marquer et al., 2009; Nabais, 2011; Uzquiano et al., 2012; Vaneeckhout et al., 2013; Yravedra \& Uzquiano, 2013), but it is not common to apply these models on faunal assemblages dating to recent prehistory, in spite of the knowledge of the combustibility of bones attested in historical times and still used in some traditional societies (Théry-Parisot et al., 2005; Crass et al., 2011).

In this paper, I test the hypothesis that the calcified faunal remains found in the Chalcolithic walled enclosure dated from the third to second millennium BC of Castanheiro do Vento, in northern Portugal, were in fact used for handling fire. The characteristics of the faunal remains recovered at the site with such high levels of calcination and fragmentation seem to confirm the possibility of using animal bones as fuel.

\section{Combustion properties of bone}

According to Costamagno et al. (2009), to evaluate the possibility of the use of animal bones as fuel, one must 
take into account the percentage of burnt bones (on average $76 \%$ of the total burnt assemblage), the fragmentation levels of the burnt bones (on average 56\% of the bones less than $20 \mathrm{~mm}$ long) and the percentage of spongy burnt bones (Costamagno et al., 2009: $67-70)$.

The various experimental studies that have been published have shown that the use of isolated bones to ignite a fire is completely ineffective. But according to the observations of Théry-Parisot (2002), fires that contain a mixture of bone fragments and wood fuel are longer lasting than those with only wood. Moreover, the combustion can be extended by the addition of bones. Therefore, it is possible to offset the cost of finding dry wood, which burns easily and requires constant addition to the fire, with the addition of animal bones to prolong combustion (Théry-Parisot, 2002).

The use of dry bones with plant fuel is controversial. Some experiments revealed that may be effective in starting the fire, leaving the addition of fresh bone to a stage where the fire has enough energy (Glazewski, 2006: 24). However, Yravedra et al. (2005) and Yravedra \& Uzquiano (2013) demonstrated that dry bone does not contribute to provide combustion.

Fresh complete bones produce better combustion, followed by the proximal fresh epiphyses, dried proximal epiphyses, shafts and distal epiphysis. The fragments less effective in combustion are the fragmented proximal epiphysis and, finally, the distal fragmented epiphyses. The proximal ends of the bones have higher levels of fat than the distal ends, but the fragmentation levels also influence the combustion. Thus, the complete epiphyses are more effective than the fragmented ones, as the fat releases faster in fragmented epiphyses (Costamagno et al., 2005). Elements from the axial skeleton also provide good combustion, as they have high contents of fat. They also allow the extension of combustion (Yravedra \& Uzquiano, 2013).

With the use of osteological material as fuel, one can obtain a staged combustion. In the first stage, combustion is very active, producing flames of appreciable size, but this quickly ceases, also ceasing combustion. The bones will not remain on fire unless accompanied by wood fuel, for when the organic material of bone is consumed, the mineral part of the bones does not burn. Only the proximal ends of the bones continue to burn for a few minutes because of the higher amount of fat (Théry-Parisot et al., 2005). Yravedra \& Uzquiano (2013) demonstrated that axial bones from medium-sized animals also extend the combustion longer.
The fire duration is also influenced by the amount of bone, the level of fragmentation and humidity levels and the presence or absence of soft tissue. Fragmentation is a key factor in the duration of combustion because fragmented bones do not burn as long as complete bones, because fragmentation promotes the release of fat more quickly. The humidity also affects the fire as a dry bone burns faster. The combustion is therefore optimized using fresh and complete bones. There are also differences in the duration of combustion depending on the different pieces of the bone used, for example, the shafts burn faster than the epiphysis (Théry-Parisot et al., 2005) while epiphysis and axial bones burn longer (Yravedra et al., 2005; Yravedra \& Uzquiano, 2013).

One of the salient features of the use of osteological elements in combustion is the lack of coal production as it happens with fuel wood. It seems that the exclusive reliance on combustion bones cannot be used in the context of long-term fire or for cooking. Therefore, the use of bones as fuel does not cover all activities that require combustion (Théry-Parisot, 2002; Théry-Parisot et al., 2005). The same experimental studies showed, however, that fires in which wood fuels are used in association with bones have a longer-lasting combustion and, on average, last onethird longer, especially if spongy bones are used. Still, the addition of bones may have been preferred when more long-lasting flames are needed (Théry-Parisot et al., 2005). This type of burning has been interpreted as an occasional choice for low-energy fire needed by upper Palaeolithic hunter-gatherers (Costamagno et al., 2005; Théry-Parisot et al., 2005; Costamagno et al., 2009).

\section{Castanheiro do Vento and the faunal assemblage}

The archaeological site of Castanheiro do Vento ${ }^{1}$ is located in the municipality of Vila Nova de Foz Côa, Guarda district, in the Alto Douro region, a few kilometres from the Palaeolithic Côa engravings, and has been excavated since 1998. While it is in an early stage of research, it already has a vast collection of radiocarbon dates that indicate that the site was occupied since the beginning of the third millennium $\mathrm{BC}$ to the first half of the second millennium BC (Cardoso, 2007, 2010) (Figure 1)

The site's typology is that of a Chalcolithic walled enclosure. It was built on top of a rounded hill, about

\footnotetext{
${ }^{1}$ Geographic coordinates $41^{\circ} 19^{\prime} 49^{\prime \prime}$ Lat. Ni $07^{\circ} 19^{\prime} 18^{\prime \prime}$ Long. W. Gr
} 


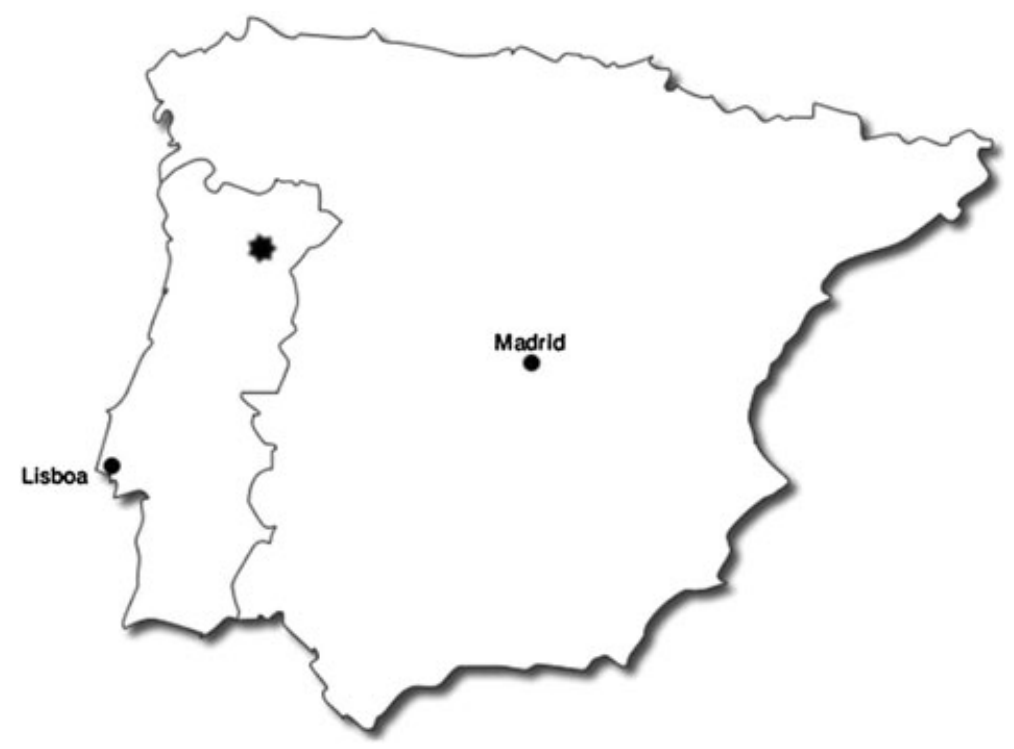

Figure 1. Location of Castanheiro do Vento in the Iberian Peninsula map.

$730 \mathrm{~m}$ high. It is characterized by an architectural stone schist, formed by three walled enclosures and a secondary enclosure, general curvilinear trend, interrupted by passages and sub-circular structures that are morphologically similar to bastions. This device consists of architectural structures in schist and represents, according to the interpretation of the archaeological team, the stony base of a superstructure built with clay and other perishable materials (Vale et al., 2006; Cardoso, 2007, 2010) (Figure 2)
Due to the geo-morphological location of the site, their stratigraphic characteristics composed by sediments resulting from the disintegration of the local schist and low rates of sedimentation, the faunal collection exhibits specific characteristics such as a small percentage of identifiable specimens and high rates of fragmentation. For this reason, the study focused predominantly on taphonomic aspects in order to reconstruct the various phenomena responsible for post-depositional

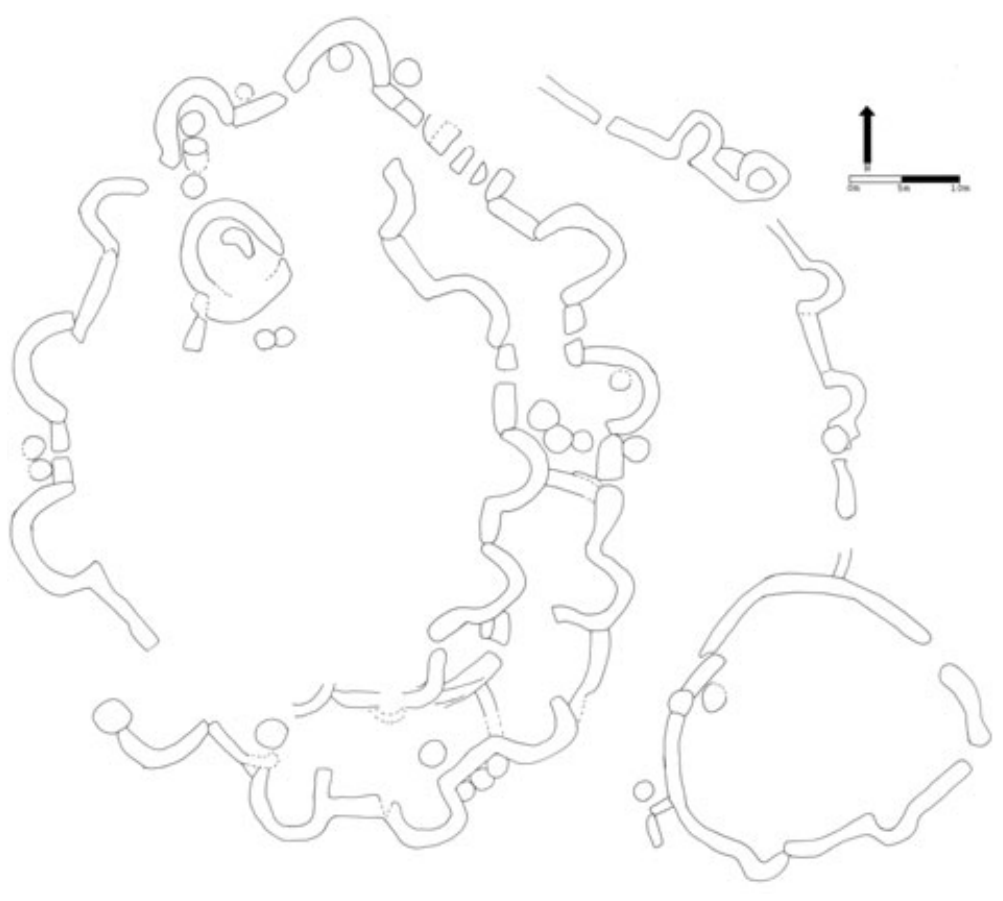

Figure 2. Plant of Castanheiro do Vento structures (until 2006 field campaign).

Copyright () 2015 John Wiley \& Sons, Ltd.

Int. J. Osteoarchaeol. 26: 877-884 (2016) 
disturbance of the original faunal accumulations (Cardoso \& Costa, 2004, Costa, 2007, 2008, 2011).

The collection is marked by a low percentage of identifiable specimens, around 5\%, resulting in a short taxonomic list. The taxa identified are suids (Sus sp.), cattle (Bos sp., Bos taurus), sheep/goat (Ovis/Capra), red deer (Cervus elaphus), horse (Equus sp.), rabbit (Oryctolagus cuniculus), five fish vertebrae (cf. Alosa sp.) and one bird element (cf. Otis tarda, great bustard) (Table 1). The main feature of the identifiable elements is an anatomic distribution dominated mainly by isolated dental remains (almost $66 \%$ of the identifiable assemblage) and limb distal ends (Costa, 2007, 2008). Ribs and vertebrae are very rare and consistent to mid-sized mammals (Table 2).

The most obvious anthropogenic marks result from thermal manipulation at high temperatures, resulting in marks consistent with carbonization (Figure 3) and calcination (Cardoso \& Costa, 2004; Costa, 2011) (Figure 4). The other evidence of anthropogenic manipulation is percussion (four elements) and cut marks (only one suid astragalus), although both cases are very rare. Also, rare are marks caused by carnivorous animals (only two bones) (Costa, 2007, 2008).

The data available demonstrate that the anthropogenic agent and natural erosion were the main factors responsible by the characteristics of the assemblage, exacerbated by the fact that most remains belong to young animals (Costa, 2007, 2008). The intense fire marks of the bones likely correspond to phases of a complex 'operational chain' of using animal bones as raw material in combustion. As a consequence, the bones broke into small pieces, allowing the influence of aeolian alteration, causing abrasion on surfaces and displacement of small-sized bones from their original position. Moreover, the low rates of sedimentation characterized by recent soil formation on top of the archaeological layers and structures exposed the entire fauna, favouring physical dissolution (Costa, 2007, 2008).

Table 1. Number of identifiable species (NISP) and minimum number of individuals (MNI)

\begin{tabular}{lrr}
\hline Species & NISP & MNI \\
\hline Equus sp. & 12 & 2 \\
Cervus elaphus & 5 & 1 \\
Bos sp. & 36 & 1 \\
Ovis/Capra & 29 & 2 \\
Sus sp. & 36 & 2 \\
Oryctolagus cuniculus & 14 & 1 \\
Alosa sp. & 5 & 1 \\
Otis tarda & 1 & 1 \\
Total & 138 & 12 \\
\hline
\end{tabular}

Copyright (C) 2015 John Wiley \& Sons, Ltd.
Table 2. Anatomical parts manipulated with fire

\begin{tabular}{|c|c|c|c|}
\hline Anatomical part & Light brown & Charred & Calcined \\
\hline Isolated teeth & & & 92 \\
\hline Crania & & 1 & 15 \\
\hline Ribs & & & 6 \\
\hline Vertebrae & & & 6 \\
\hline Scapulae & & & 4 \\
\hline Humerus & & & 3 \\
\hline Radius & & & 1 \\
\hline Ulnae & & 1 & \\
\hline Innominate & & & 3 \\
\hline Femur & & & 2 \\
\hline Tibia & & & 1 \\
\hline Fibula & 1 & & \\
\hline Metapodials & & 1 & 8 \\
\hline Carpals/Tarsals & & & 4 \\
\hline Phalanges & & & 14 \\
\hline Unidentifiable spongy bone & & & 71 \\
\hline
\end{tabular}

\section{Archaeological contexts}

The faunal materials presented here come from all archaeological contexts excavated up to the 2010 field season. The bones showing evidence of manipulation by fire are found in the interior of micro-structures found in the bastions, such as small pits, fireplaces and other kinds of combustion structures. These pits are frequently not clearly visible and sometimes are detected only by changes in the sediment colour, characterized by a great amount of charcoal and ash, without any structural organization. The combustion features reveal the same characteristics. Although formed by thermally altered stones, still sometimes they cannot be clearly

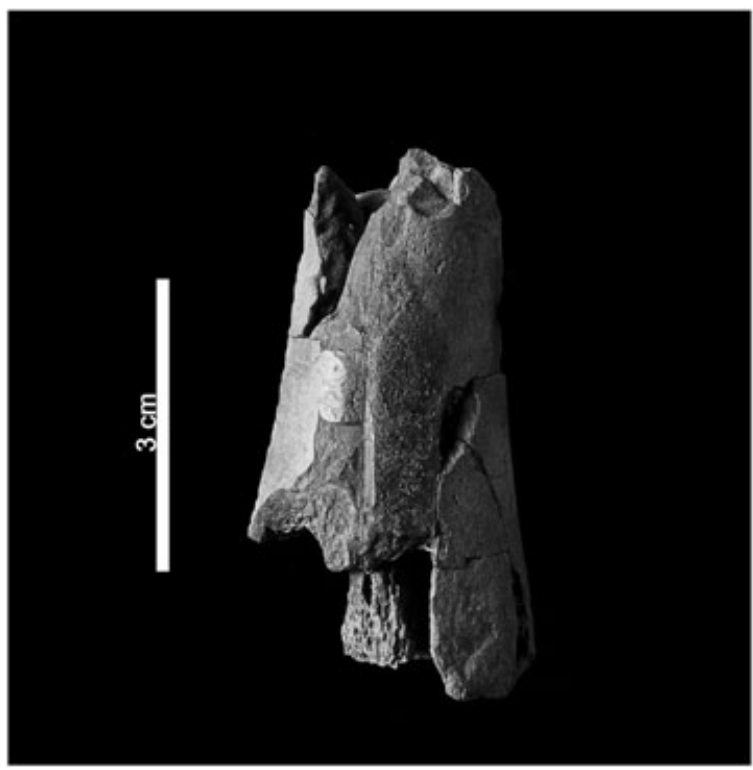

Figure 3. Example of charred bone.

Int. J. Osteoarchaeol. 26: 877-884 (2016) 


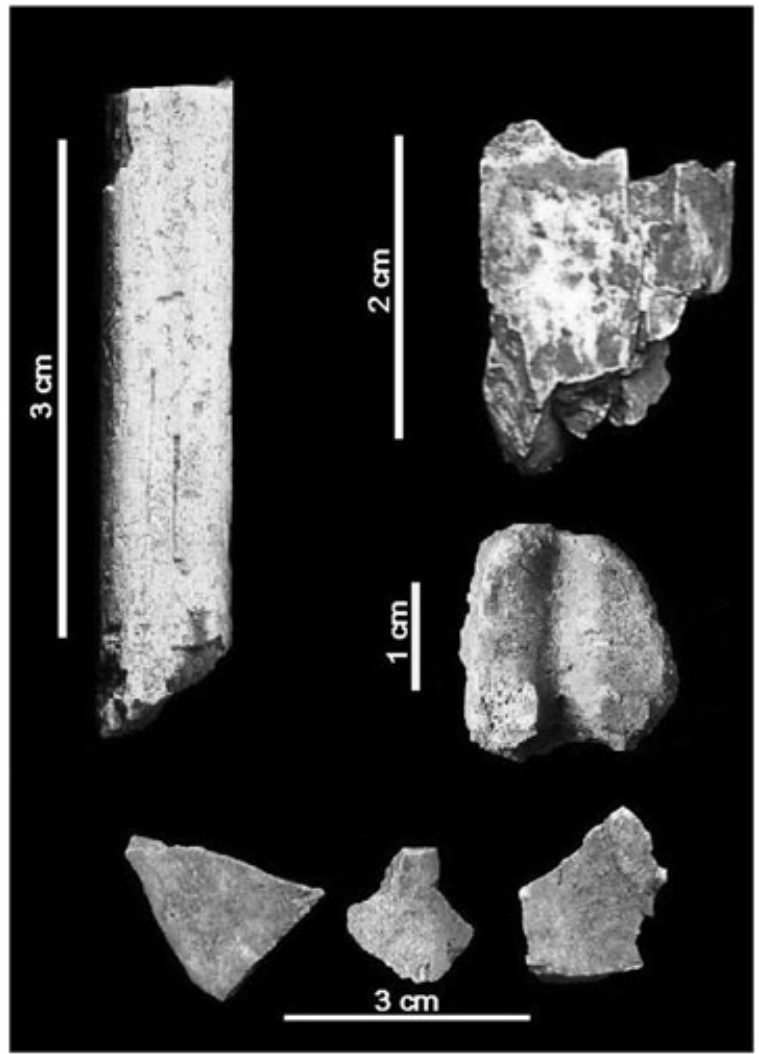

Figure 4. Examples of calcined bones.

identified. The common characteristic of these microfeatures is related to the characteristics of the sediment, which is very dark, with high concentrations of ash and charcoal and small-sized charred bones.

Another part of the material comes from an archaeological layer that develops inside the bastion $\mathrm{E}$, which is characterized by very dark and fine-grained sediment, with a high concentration of burnt small-sized material.

The stratigraphic features associated with other archaeological contexts, like walls or other stony structures, also provided bone assemblages with marks of thermal manipulation, although in smaller numbers.

\section{The burnt bones of Castanheiro do Vento}

Although bone colour is not a fail-proof method of determining fire intensity (Lyman, 2001: 385), it was an important factor in defining the classification classes. The colour changes in burned bone results from chemical reactions of the organic component that accelerates with each increase in temperature by $10^{\circ} \mathrm{C}$. In this case, some authors agree that the colour changes on bone roughly represent the temperature range (Buenger, 2003:29).
A full $91.9 \%$ of faunal remains from Castanheiro do Vento showed evidence of thermal manipulation (Table 3). These were classified into four stages of heat intensity, based mainly on the observation of colour: unburned, slightly burnt, charred, and calcined. The stadium slightly burnt corresponds to a light-brown, uneven colour, which results from short exposure to intense fire. Charred refers to a dark-black and uniform colouration. Calcined corresponds to calcination and is represented by a colour between grey and white as the result of a prolonged and intense combustion (Walker \& Miller, 2005).

Other features were also analyzed such as cracking and the level of contraction of the initial mass of bone and distortion of the initial morphology. In pursuing this analysis, it was discovered that the highest levels of cracking, borrowing and morphological distortion occurred on calcined bones.

Of the 2775 bones and teeth that make up the sample, 2550 (about 92\%) exhibit a white/grey colouration as a result of the calcination process (Figure 4), 208 $(7.5 \%)$ remains do not show any level of fire manipulation, only $13(0.5 \%)$ present a dark-black colour compatible with the carbonization (Figure 3), and finally, $4(0.1 \%)$ have a light-brown colour, as a result of submission to less intense heat (Table 3 ).

\section{Calcined bones}

Calcination on a bone begins with exposure to temperatures from $600{ }^{\circ} \mathrm{C}$ to $700^{\circ} \mathrm{C}$. From this stage, bone loses plasticity and organic matter, decalcifies and twists (Lyman, 2001). Stiner et al. (1995) argue that calcination is only possible if there is direct contact with the fire, and it is a mark connected with the fire of anthropogenic origin. Accidental burning of the bone, which may occur when cooking meat, leads to an uneven colour on the bone surface, and the effect of combustion tends to be superficial with no carbonization or calcination (Cain, 2005: 875).

The fragmentation rate of calcined bones at Castanheiro do Vento is very high, with $84.9 \%$ of the fragments smaller than $10 \mathrm{~mm}$ (Table 4). Most remains had abraded, rounded edges $(66.7 \%)$, making it

Table 3. Totals of the various stages of thermal manipulation

\begin{tabular}{lrr}
\hline Thermal intensity & \multicolumn{1}{c}{$N^{\circ}$} & $\%$ \\
\hline Calcination & 2550 & 91.9 \\
Carbonization & 13 & 0.5 \\
Slightly burnt & 4 & 0.1 \\
Not burnt & 208 & 7.5 \\
Total & 2775 & 100 \\
\hline
\end{tabular}

Int. J. Osteoarchaeol. 26: 877-884 (2016) 
Table 4. Fragmentation pattern of the calcined remains

\begin{tabular}{lrr}
\hline Fragments mm & $N^{\circ}$ & $\%$ \\
\hline$<10$ & 2180 & 84.9 \\
$11-15$ & 212 & 8.3 \\
$16-20$ & 106 & 4.2 \\
$21-25$ & 37 & 1.4 \\
$26-30$ & 7 & 0.3 \\
$31-35$ & 13 & 0.5 \\
$36-40$ & 6 & 0.2 \\
$41-49$ & 2 & 0.1 \\
$>50$ & 4 & 0.2 \\
Total & 2567 & 100 \\
\hline
\end{tabular}

impossible to analyze the type of fracture. It was noted, however, that 190 of the calcined remains exhibit recent fractures $(7.5 \%)$, resulting from handling the remains during excavation, 665 pieces exhibit dry breaks $(26 \%)$, resulting from the calcination process (Table 5 ), of which $325(69 \%)$ correspond to small splinters with dimensions less than $10 \mathrm{~mm}$ long (Costa, 2011).

This pattern suggests that, in the case of calcined bones, the high number of fragments is due to the fragmentation caused by thermal action, with the intentional fracturing prior to handling the fire, residually represented. In addiction, calcification decreases the plasticity of bone, and therefore, it is likely to be fractured in the ground due to trampling (Thiébaut et al., 2010) and the weight of soil and sediments and to weathering processes (Gerbe, 2010).

\section{Charred bones}

The exposure of a bone to temperatures between $250^{\circ}$ $\mathrm{C}$ and $550^{\circ} \mathrm{C}$ causes carbonization of the original collagen, which gives the bone a black colouration. These temperatures also initiate the process of fragmentation with the appearance of first cracks (Buenger, 2003). In this sample, there is a total of 13 fragments that exhibit a dark-black colour, compatible with the process of carbonization. Of these, five are smaller than $10 \mathrm{~mm}$ long, and the larger fragment is $55.3 \mathrm{~mm}$ long.

It was not possible to observe the fracture of many of these bones, due to the small size of the bones and the abrasion on many edges. However, a distal epiphysis of a Cervus elapbus metacarpus (Figure 3) and a fragment of

Table 5. Breaks of the calcined bones

\begin{tabular}{lcc}
\hline Breaks & $N^{\circ}$ & $\%$ \\
\hline Abraded and rounded breaks & 1712 & 66.7 \\
Dry break & 665 & 25.9 \\
Recent break & 190 & 7.4 \\
Total & 2567 & 100 \\
\hline
\end{tabular}

Copyright (C) 2015 John Wiley \& Sons, Ltd.
Bos sp. skull exhibit dry breaks, which may be related to the process of thermal cracking.

\section{Mild thermal manipulation (sligbtly burnt)}

The lighter colours, extending from variations of yellow to brown, correspond to minimal exposure times and temperatures up to $285^{\circ} \mathrm{C}$. From this point, the first cracks may appear, even if the original surface still remains intact (Buenger, 2003).

Of the four remains that were lightly burnt, two are fragments of long bones diaphyses: a Sus sp. fibula shaft displaying intense polishing, and a diaphysis of an undetermined middle-sized animal long bone. The other two fragments were not identifiable. These remains are also very small, while the largest is $71.4 \mathrm{~mm}$ long and the smaller $32.4 \mathrm{~mm}$ long.

\section{Discussing burning bones at Castanheiro do Vento}

As described earlier, the available data from Castanheiro do Vento assemblage confirm the predominance of calcined remains, with a fairly high degree of fragmentation, dominated by fragments smaller than $10 \mathrm{~mm}$ long. This is likely the result of thermal cracking. Assuming that neither natural nor accidental fires cause carbonization or calcination (Stiner et al., 1995; Cain, 2005) and that site maintenance is inferred through faunal assemblage with around $50 \%$ of burned bones, wherein $99 \%$ is charred and not calcined bone (Dibble et al., 2009), we must accept the hypothesis that the remains from Castanheiro do Vento were intentionally burned. In that site, burnt bones represent almost $92 \%$ of the assemblage (Table 3), the percentage of burnt bones with dimensions less than $20 \mathrm{~mm}$ long is around $98 \%$ (Table 4) and the calcined bones are those with more diminutive size.

The percentage of burned spongy bone, however, amounts to only $2.8 \%$ (up to 71 bones, Table 2 ). According to the experimentation models, the rate of cancellous bone fragments is a key indicator in the identification of this practice. This is due to the fact that the combustible properties of fat in bones make the bones burn longer (Costamagno et al., 2009: 68). The high percentage of very small bones, less than $20 \mathrm{~mm}$, prevented the classification as spongy bone. Also, calcined spongy bone is particularly sensitive to post-depositional processes (Gerbe, 2010), which probably accounts for its low representation in the Castanheiro do Vento assemblage. In contrast to the 
high percentage of burned bone, there is a low percentage of fire manipulated teeth, only 3.2\% (90 teeth and tooth fragments). The bone collection from Castanheiro do Vento is characterized by $3.9 \%(n=107$, Table 2$)$ isolated teeth and tooth fragments, but only $0.8 \%(n=22)$ of the total assemblage represents other cranial fragments, almost all burned ( $n=15$, Table 2). This discrepancy between the number of isolated teeth and other cranial fragments is difficult to explain and maybe is due to the physical dissolution that affects particularly bones from the skull. Anyway, the extreme majority of these cranial fragments are burnt, contrasting with the number of teeth unburned. At this level of knowledge, it is difficult to interpret these proportions, but removing the teeth, which have less combustion capacity previous to burning the skull pieces, should be considered.

The available data indicate that there is a variability of anatomical parts calcined, from teeth to metapodials and phalanges (Table 2). Likewise, there is no selection of species; on the contrary, every taxa are fire manipulated, except for the Otis tarda carpal. However, the overwhelming majority of remains completely impossible to identify both anatomically and taxonomically indicate that we cannot clarify which anatomical sections were preferred to the fire.

\section{Final remarks}

The structural complexity of a settlement such as Castanheiro do Vento, on the one hand, and the initial state of the investigations at the site, on the other, will not allow, presently, to understand in what social context activities related to the use of fire occurred. The results presented here are preliminary, but in the future, the number of archaeofaunal remains will certainly increase, and with more excavation, it will be possible to better understand the structural and stratigraphic associations related to burnt bones.

In the near Chalcolithic site of Crasto de Palheiros (also in Alto Douro Region), the faunal remains also revealed a high percentage of calcined bones in an assemblage with taphonomic characteristics (Cardoso, 2005) very similar to Castanheiro do Vento. Thus, a cultural option of using animal bones as fuel is likely and must, thus, be considered.

The analysis of the faunal collection available from the pre-2010 excavations of Castanheiro do Vento shows certain characteristics such as the high rate of calcination and fragmentation, suggesting the use of bones as fuel. There is also a low amount of charcoal compared with the percentage of burnt bones (personal communication from J. Muralha Cardoso), which is another of the criteria used in demonstrating the use of bones as fuel (Théry-Parisot, 2002; Cain, 2005: 881).

The major part of the bones exhibit a uniform colour in both the calcined or charred remains, pointing to the submission of the bone to fire uniformly and without coating of soft tissue (Asmussen, 2009).

By the specific characteristics of combustion with bones, I argue that its use intentionally and strategically requires mastery of the technique, knowledge of the different combustion potential for each part of the bone, control of humidity levels and general knowledge of how to combine bone with fuel and when to introduce more bones to the fire. Neither the quantity nor the quality of combustion satisfies all the required needs, but it may have been used for specific activities (Théry-Parisot et al., 2005) requiring more lasting flame (Costamagno et al., 2009). Moreover, wood fuel is a much more abundant resource than bones, so the use of animal bones in hearths should be seen as a response to specific activities (Théry-Parisot et al., 2005: 57). Given our present state of knowledge about Castanheiro do Vento, we cannot put forward a viable hypothesis on which activities required the use of bone fuel.

Combustion activities are quite variable, motivated by different needs and conditioned by several factors, both inherent in the internal organization of the human community and external, such as the constraints of environment and season.

\section{References}

Asmussen B. 2009. Intentional or incidental thermal modification? Analysing site occupation via burned bone. Journal of Archaeological Science 36: 528-536.

Buenger BA. 2003. The impact of wild land and prescribed fire on archaeological resources. Submitted to the Department of Anthropology and the Faculty of the Graduate School of the University of Kansas ain partial fulfilment of the requirements for the degree of Doctor in Philosophy.

Cain CR. 2005. Using burned animal bone to look at Middle Stone Age occupation and behaviour. Journal of Archaeological Science 32: 873-884.

Cardoso JCM. 2007. Castanheiro do Vento (Horta do Douro, Vila Nova de Foz Côa). Um recinto monumental do $\mathrm{III}^{\circ}$ e $\mathrm{II}^{\circ}$ milénio a. C.: problemática do sítio e das suas estruturas à escala regional. $\mathrm{PhD}$ dissertation presented to Faculty of Letters of University of Oporto.

Cardoso JCM. 2010. Castanheiro do Vento (Horta do Douro, Vila Nova de Foz Côa). Um recinto monumental do $\mathrm{III}^{\circ}$ e $\mathrm{II}^{\circ}$ milénio a. C.: problemática do sítio e das suas estruturas à escala regional. Palma de Maiorca, Ilhas Baleares, Vessants arqueologia i cultura.

Int. J. Osteoarchaeol. 26: 877-884 (2016) 
Cardoso JL. 2005. Restos faunísticos do Crasto de Palheiros (Murça). Contributo para o conhecimento da alimentação no Calcolítico e na Idade do Ferro no Nordeste Português Portugália XXVI: 65-75.

Cardoso JL, Costa C. 2004. A study of the faunal assemblage from the prehistoric enclosure of Castanheiro do Vento (Vila Nova de Foz Côa). Journal of Iberian Archaeology 6: 83-92.

Costa C. 2007. Zooarqueologia e tafonomia de Castanheiro do Vento. Master thesis presented to Faculty of Human and Social Sciences of University of Algarve.

Costa C. 2008. Aspectos tafonómicos em Castanheiro do Vento com base na análise da arqueofauna. Promontoria 6: 159-221.

Costa C. 2011. A gestão do fogo em Castanheiro do Vento: a possível utilização de ossos de animal como combustível. Proceedings II Jornadas de Jóvenes en Investigación Arqueológica (Madrid, 6, 7 y 8 de mayo de 2009). Tomo I. Madrid: Libro Portico: 309-315.

Costamagno S, Théry-Parisot I, Brugal JP, Guibert R. 2005. Taphonomic consequences of the use of bones as fuel. Experimental data and archaeological applications. $\mathrm{T}$. O'Connor, (ed.), Biosphere to Lithosphere. New studies in vertebrate taphonomy, Oxbow Book, Proceedings of the 9th ICAZ Conferences of the International Council of Archaeozoology: Durham, August 2002: 51-62.

Costamagno S, Théry-Parisot I, Castel JC, Brugal JP. 2009. Combustible ou non? Analyse multifactorielle et modèles explicatifs. Théry-Parisot I Costamgno S Henry A. (ed.), Gestion des combustibles au paléolithique et au mesolithique. Nouveaux outils, nouvelles interpretations, Proceedings of the XV world Congress (Lisbon, 4-9 September, 2006) 13: 65-84.

Crass, BA, Kedrowski, BL, Baus, J, Behn JA. 2011. Residue analysis of bone-fueled Pleistocene hearths. Goebelt, T, Buvit, I. From the Yenisei to the Yukun. Interpreting lithic assemblage variability in Late Pleistocene/Early Holobcene Beringia, Texas A and M University Press

Dibble H, Berna F, Goldberg P, McPherron SP, Mentzer S, Niven L, Richter D, Sandgate D, Théry-Parisot I, Turq A. 2009. A preliminary report on Pech de l'Azé IV, Layer 8 (Middle Paleolithic, France). PaleoAntbropology: 182-219. DOI: 10.4207/PA.2009.ART30.

Gerbe M. 2010. The action of weathering on burned bone: an experimental approach. The taphonomy of burned organic residues and combustion features in archaeological contexts, Théry-Parisot I, Chabal L, Costamagno S. (eds). Proceedings of the round table, Valbonne, May 27-29 2008. P@lethnologie 2:185-196.

Glazewski M. 2006. Experiments in bone burning. Oshkosh Scholar: 17-25.

Lyman RL. 2001. Vertebrate Taphonomy. Cambridge University Press: Cambridge.

Marquer L, Otto T, Nespoulet R, Chiotti L. 2009. New approach to study the fuel used in hearths by hunter-gathers at the Upper Paleolithic site of Abri Pataud, Dordogne, France. Journal of Archaeological Science 37: 2735-2746.

Nabais M. 2011. The Neanderthal occupation of Gruta da Oliveira (Almonda Karstic System, Torres Novas, Portugal).
Analysis of the burnt bones. Proceedings of the II Jornadas de Jóvenes en Investigatión Arqueológica (Madrid, 6, 7 y 8 de mayo de 2009). Tomo I. Madrid: Libros Portico: 381-385.

Stiner M, Kuhn S, Weiner S, Bar-Yosef O. 1995. Differential burning, recrystallization, and fragmentation of archaeological bone. Journal of Archaeological Science 22: 223-237.

Théry-Parisot I. 2002. Fuel management (bone and wood) during the lower Aurignacian in the Pataud rock shelter (Lower Palaeolithic), Les Eyzies de Tayac, Dordogne, France): contribution of experimentation and anthracoanalysis to the study of the socioeconomic behaviour. Journal of Archaeological Science 29: 1415-1421.

Théry-Parisot I, Costamagno S. 2005. Priprietés combustibles des ossements. Donnés experimentales et réflexions archéologiques sur leur emploi dans les sites paléolithiques. Gallia Préhistoire. 47: 235-254.

Théry-Parisot I, Costamagno S, Brugal JP, Fosse P, Guilbert R. 2005. The use of bone as fuel during the Palaeolithic, experimental study of bone combustible properties. J Mulville J Outram A. (Eds.). The Archaeology of Milk and Fats, Proceedings of the 9th ICAZ Conferences. Durham 2002: 50-59.

Thiébaut C, Costamagno S, Coumont M-P, Mourre V, Provenzano N, Théry-Parisot I. 2010. Approche expérimentalle des conséquences du piétinement des grands herbivores sur les vestiges lithics et osseux. Supplément a Paleo 3: 109-129.

Uzquiano P, Yravedra J, Ruiz Zapata B, Gil Garcia MJ, Sesé C, Baena J. 2012. Human behaviour and adaptations to MIS 3 environmental trends (>53-30kyrs BP) at El Esquilleu Cave (Cantabria). Quaternary International 252: 82-89.

Vale AM, Cardoso JM, Jorge VO. 2006. Recintos murados e /ou colinas monumentalizadas no nordeste de Portugal? $\mathrm{O}$ caso de castanheiro do Vento, Vila Nova de Foz Côa. Correia M, Jorge VO (ed) Terra: forma de construir Arquitectura Antropologia Arqueologia 10 a Mesaredonda de Primavera. Argumentum: 98-105.

Vaneeckhout S, Salmi A-K, Junno J-A. 2013. Archaeological refuse fauna in Finland: understanding the role of bone combustion. Antbropozoologia 48(1): 125-134. DOI: $10.5252 / a z 2013 n 1 a 7$.

Villa P, Bon F, Castel JC. 2002. Fuel, fire and fireplaces in the Palaeolithic of western Europe. The review of Archaeology 23: 33-42.

Walker PL, Miller KP. 2005. Time, temperature, and oxygen availability: an experimental study of the effects of environmental conditions on the colour and organic content of cremated bone. American Journal of Pbysical Antbropology 126, supplement 40: 222.

Yravedra J, Uzquiano P. 2013. Burnt bone assemblage from El Esquileu cave (Cantabria, northern Spain): deliberate use for fuel or systematic disposal waste? Quaternary Science Reviews 68: 175-190.

Yravedra J, Baena J, Arrizabalaga A, Iriarte MJ. 2005. El empleo de material óseo como combustíble durante el Paleolítico Médio e Superior en el Cantábrico. Observaciones experimentales. Museo de Altamira Monografias 20: Santander: 369-383. 